\title{
PENGARUH BRAND ASSOCIATION TERHADAP CONSUMER RESPONSE PADA PRODUK LOUIS VUTION DI SURABAYA
}

\author{
Angela Stephani, Indarini, Christina Rahardja Honantha* \\ Fa kultas Ekonomi UBAYA
}

\begin{abstract}
Louis Vuitton is known with initial LV and also a brand that affected consumer in decision making. Brand Association are attributes linked to the brand by customers that is detemined with the guarantee function, the personal identification function, the social identification function, dan the status function. Consumer response is an effort to satiffy a drive. Reaction evoked by a stimulus consumer response, which it is detemined with willingness to pay a price premium for the brand, willingness to accept brand extentions, dan willingness to recommend the brand to other. This research aim to test the effect of brand association of LV to consumer response with linier regression. The result shows that brand association of LV affect consumer response signific antly.
\end{abstract}

Keywords: Brand Association, Consumer Response

\section{PENDAHULUAN}

Bagi banyak orang penampilan adalah sesuatu yang sangat penting bahkan penampilan tersebut harus didukung dengan produk bermerek yang eksklusif. Bagi kalangan tertentu masalah harga tidak menjadi masalah sebab yang paling penting adalah produk bemerek bisa membuat bangga para pemakainya seka ligus mengangkat derajat pemaka inya (Sma rt shopping, 13 Mei 2005).

Pada saat ini di Indonesia sudah banyak terdapat branded fashion store seperti Louis Vuitton, Aigner, Hugo Boss, Gucci, Prada, Burbemy, Bally, Giani Versace, Bottega Veneta dan la in sebagainya, dimana target pasar adalah konsumen menengah ke atas. Produk-produk yang dijual oleh branded fashion tersebut beragam mulai dari baju, tas, dompet, sabuk, syal, dan sebagainya. Sebagian besar branded fashion store yang ada di Indonesia terletak di kota Jakarta. Di Surabaya yang menjual produk bermerek tersebut tidaklah sebanyak di Jakarta dan hanya terdapat merek tertentu seperti Aigner, Hugo Boss, Gianni Versace, Louis Vuitton, dan Bally.

Orang merasa lebih berkelas dan bangga bila menggunakan barang bermerek. Seorang karyawati mungkin rela mengeluarkan uang lebih banyak dan bersedia menyisihkan gajinya untuk mencicil selama setahun demi sebuah tas Louis Vuitton, Channel, Gucci, Prada, dan sejenisnya. Gaya hidup adalah perilaku seseorang 
yang ditunjukkan dalam aktivitas, minat dan opini khususnya yang berkaitan dengan citra din untuk merefleksikan status sosialnya. Untuk merefleksikan image inilah, dibutuhkan simbol-simbol status tertentu, yang sangat berperan dalam mempenga ruhi perilaku konsumsinya (www.jaka rtaconsulting. com).

Berdasarkan wawancara terhadap 30 orang yang menggunakan produk branded fashion, didapatkan data seperti di bawah ini:

Tabel 1

\begin{tabular}{clccc}
\multicolumn{2}{c}{ PRODUK BRANDED FASHION YANG SERING } & DIBEU OLEH RESPO NDEN DI SURABAYA \\
\hline No & & PRODUK & FREKUENSI & \% Frekuens \\
\hline 1 & Louis Vuitton & 20 & 66.67 \\
2 & Gucci & 6 & 20 \\
3 & Hugo Boss & 3 & 10 \\
4 & Versace & 1 & 3.33 \\
\hline \multicolumn{2}{l}{ TOTAL } & 30 & 100
\end{tabular}

Sumber. hasil wawancara, November 2007, diolah.

Berdasarkan hasil polling tersebut, maka pada akhimya diambil 1 hasil pilihan terbesar dari responden yaitu branded fashion Louis Vuitton untuk digunakan sebagai obyek pada penelitian ini dimana persentase responden yang memilih branded fashion store Louis Vuitton a dalah sebesar 66,67\%.

Alasan sebagian besar konsumen yang memilih merek Louis Vuitton atau yang lebih populer dengan singkatan LV adalah merek LV memiliki image, prestige, dan lebih berkelas. Hal ini dikarenakan memang harganya lebih mahal bila dibandingkan dengan merek-merek yang lain sehingga terasa lebih berkelas apabila menggunakan merek LV. Selain itu juga karena produk Louis Vuitton tidak pemah memberikan diskon (sale). Menurut salah seorang konsumen, meskipun klasik, LV lebih fashionable dibandingkan merek lainnya. Harga dari tas LV berbeda-beda. Tergantung dari kualitas kulit yang digunakannya (www.korantempo.com). Jenis monogram harganya berkisar Rp 12 juta, multicolor sekitar Rp 12,5 juta, dan EPI leather sekitar Rp 15 juta. Sedangkan LV Suhali leather harganya dapat mencapai angka Rp 23 juta - Rp 35 juta (www.louisvuitton.com).

Merek Louis Vuitton yang ada di Indonesia merupakan franchise yang dipegang oleh PT Bagasi Lux, Gedung Artha Graha 26F, jalan Jendral Sudiman Kav 52-53 Jakarta, yang juga pemegang franchise produk Celine (Wa rta Ekonomi, Selasa, 6 J uni 2006). Louis Vuitton adalah perusahaan branded fashion dan barang-barang dari kulit di Perancis. Perusahaan membuat dan menjual barang-barang kulit yang mewah, aksesoris, prêt-à-porter, dan perhiasan. Perusahaan hanya menjual produknya melalui tokonya sendini di seluruh dunia, sehingga dapat mengendalikan mutu produk dan penetapan harga, untuk mencegah pemalsuan produk memasuki saluran distribusinya. Sebagai tambahan, perusahaan menggunakan 
single online retailer untuk menjual sebagian produknya. Tanda tangan Louis Vuitton dianggap sebagai simbol status dan dihargai di seluruh dunia fashion (www.wikipedia.org).

Tingkat penjualan saham Louis Vuitton yang selalu meningkat dapat menunjukkan bahwa produk branded fashion Louis Vuitton tetap diminatioleh pasar.

"The owner of the Louis Vuitton fashion house said that its sales for the first nine months of the year rose 8 per cent to Euros 11.446bn (Dollars $16.2 \mathrm{bn}$ ), beating a consensus forecast of Euros $11.292 \mathrm{bn}$ obtained through a Reuters poll of analysts. The better-than-expected figures came after growth accelerated to 10 per cent in the third quarter of the year, in spite of an export headwind created by the strong euro. LVMH said it still expected "a significant increase in its results in 2007" in spite of the exc essive value of the euro". (Fina ncial Times, 16 O ktober 2007).

Berdasarkan kutipan di atas dapat diketahui bahwa penjualan toko Louis Vuitton dalam sembilan bulan pertama tahun 2007 mengalami peningkatan sebesar 8\% melalui sebuah survei yang dilakukan oleh Reuters. Hal ini bahkan lebih bagus dari perkembangan yang telah dibayangkan dan pihak toko Louis Vuitton masih mengharapkan adanya peningkatan lagi pada tahun ini.
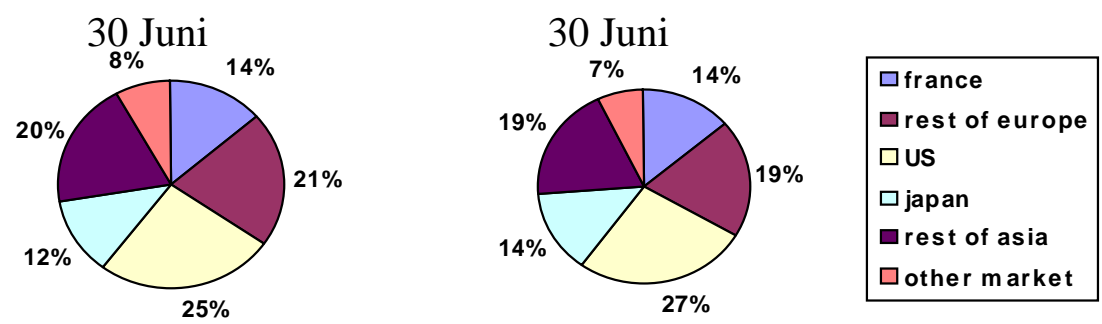

\section{Gambar 1 \\ PENDAPATAN LOUISVUITTON BERDASARKAN PEMBAGIAN GEOG RAFIS Sumber: www.Ivmh.com, diolah}

Gambar 1 di atas menggambarkan bahwa pendapatan Louis Vuitton di Indonesia yaitu yang termasuk dalam wilayah rest of asia sebanyak $19 \%$ dari total pendapatan Louis Vuitton pada tahun 2006 dan meningkat menjadi 20\% dari total pendapatan Louis Vuitton di seluruh dunia pada tahun 2007.

Selanjutnya revenue atau pendapatan Louis Vuitton selama 3 periode selalu meningkat. Pada periode 30 Juni 2005 pendapatannya sebesar EUR 2,196 juta, 
pada periode 30 J uni 2006 meningkat menja di EUR 2,466 juta, dan pa da periode 30 J uni 2007 menjadi EUR 2,601 juta. Hal ini menandakan bahwa respon konsumen yang meningkat sehingga penjualan produk Louis Vuitton ikut meningkat. Sedangkan pesaingnya Gucci, meskipun juga mengalami peningkatan tetapi jumlah pendapatannya tidak sebesar Louis Vuitton.

Oleh karena itu dapat dilihat bahwa Louis Vuitton mempunyai revenue dan peringkat yang lebih tinggi dibanding dengan pesaing-pesa ingnya.

Tabel 3

THE 100 TOP BRANDS 2006-2007

\begin{tabular}{cclllll}
\hline $\begin{array}{c}2006 \\
\text { Rank }\end{array}$ & $\begin{array}{r}2007 \\
\text { Rank }\end{array}$ & Nama & $\begin{array}{c}\text { Negara } \\
\text { Asal }\end{array}$ & $\begin{array}{c}2006 \text { value } \\
(\$ \text { mil) }\end{array}$ & $\begin{array}{r}2005 \\
\text { value } \\
(\$ \text { mil) }\end{array}$ & $\begin{array}{c}\text { Change } \\
\text { in value } \\
(\%)\end{array}$ \\
\hline 17 & 18 & Louis Vuitton & France & 17,606 & 16,077 & $10 \%$ \\
46 & 49 & Gucci & Italy & 7,158 & 6,619 & $8 \%$ \\
61 & 65 & Chanel & France & 5,156 & 4,778 & $8 \%$ \\
96 & 93 & Prada & Italy & 2,874 & 2,760 & $4 \%$ \\
\hline
\end{tabular}

Sumber. www.businessweek.com, diolah.

Brand Association atau asosiasi merek Louis Vuitton adalah segala sesuatu dalam memori yang berhubungan dengan merek Louis Vuitton. Merek Louis Vuitton diasosiasikan oleh konsumennya sebagai produk branded fashion yang mahal dan mewah. Suatu merek yang telah terkenal akan memiliki posisi yang menonjol dalam persaingan bila didukung berbagai asosiasi yang kuat.

Sigi awal temadap branded fashion yang dibeli oleh responden di Surabaya didapat 20 responden yang memilih produk Louis Vuitton, maka dapat diketahui tanggapan para konsumen terhadap elemen-elemen brand associations Louis Vuitton sebagai produk branded fashion. Hasil yang didapat adalah sebagai berikut: dari empat pertanyaan yang diajukan kepada 20 orang responden, di mana pertanyaan-pertanyaan yang diajukan mewakili setiap elemen pengukur dari brand associations didapatkan hasil bahwa sebanyak 87,5\% memberikan penilaian positif terhadap brand associations produk Louis Vuitton sedangkan sisanya yang sebanyak 12,5\% memberikan penilaian negatif terhadap brand associations produk Louis Vuitton.

Selanjutnya sigi awal juga untuk mengetahui tanggapan para responden terhadap elemen-elemen consumer response Louis Vuitton sebagai produk branded fashion, juga dilakukan wawancara terhadap 20 orang responden tersebut untuk mengetahui respon mereka terhadap produk Louis Vuitton. Hasilnya sebanyak 93,33\% memberikan tanggapan yang positif terhadap produk Louis Vuitton, sedangkan sisanya yang sebanyak $6,67 \%$ memberikan tanggapan yang negatif terhadap produk Louis Vuitton. 


\section{Identífikasi Permasalahan}

Brand atau merek merupakan hal yang penting sebab dapat mempengaruhi para konsumen dalam mengambil keputusan untuk melakukan pembelian. Respon konsumen terhadap branded fashion Louis Vuitton tergantung dari berbagai hal misalnya kualitas produk, bentuk atau model produk, dan harga yang berkaitan dengan merek tersebut.

Dari hasil sigi awal yang telah dilakukan melalui wawancara terhadap brand associations produk Louis Vuitton dan consumer response produk Louis Vuitton, menunjukkan adanya kecendenungan bahwa brand associations produk Louis Vuitton mempunyai hubungan dengan consumer response. Dengan demikian dapat diteliti pengaruh brand associations terhadap consumer response branded fashion Louis Vuitton di Surabaya.

\section{lingkup Bahasan}

Pada penelitian ini menggunakan konsep brand association menunut Aaker (1991:109) ya itu: "Brand association is anything linked in memory to a brand and not only exists but has a level of a strength" ya kni a so siasi merek sebagai segala sesuatu dalam memori yang berhubungan dengan merek dan bukan hanya eksis tetapi juga memiliki tingkat kekuatan. Elemen pengukuran brand association menurut $A$. Belen del Rio, et al. (2001) yaitu the guarantee function, the personal identification function, the social identific ation function, dan the statusfunction.

Consumer response menurut Keegan (1995:7) dan Dictionary Of Marketing and Business Terms yaitu pencerminan dari sikap dan perilaku pengguna produk dalam memua skan dorongan yang ada sebagai reaksi terhadap usaha-usaha pemasaran yang dilaksanakan perusahaan. Elemen pengukuran menurut $A$. Belen del Rio, et al. (2001) yaitu willingness to pay a price premium for the brand, willingness to accept brand extensions, dan willingness to recommend the brand to others.

\section{Penumusan Masalah}

Berdasarkan pembatasan masalah dan setelah dikaitkan dengan hasil di atas, maka dapat dirumuskan masalah sebagai berikut: "Apakah ada pengaruh brand association terha dap consumer response produk Louis Vuitton di Surabaya?"

\section{Tujuan dan Manfaat Penelitian}

Tujuan dari penelitian ini adalah untuk mengetahui dan menganalisis besamya pengaruh brand association terhadap consumer response produk Louis Vuitton di Surabaya. Sedangkan manfaat penelitian ini adalah untuk memberikan masukan 
kepada produsen sebagai bahan pertimbangan dalam menjaga dan meningkatkan brand association dari produk Louis Vuitton sehingga respon positif dari konsumen dapat terpelihara, yang nantinya akan meningkatkan loyalitas dari para pelanggan terhadap produk Louis Vuitton.

\section{LANDASAN TEORI DAN PENGEMBANGAN HIPOTESIS}

\section{Brand Association}

Menurut Aaker (1991:109) a dalah: "Brand association is anything linked in memory to a brand and not only exists but has a level of a strength" yakni asosiasi merek sebagai segala sesuatu dalam memori yang berhubungan dengan merek dan bukan hanya eksis tetapi juga memiliki tingkat kekuatan. Asosiasi merek dapat memiliki bentuk yang berbeda-beda. Salah satu cara untuk membedakan asosiasi merek adalah pada tingkat abstraksinya, yaitu berupa banyak informasi yang terangkum atau tema suk dalam a sosiasi.

Durianto, et al. (2001:69) mendefinisikan a sosiasi merek sebagai kesan yang muncul di benak seseorang yang terkait dengan ingatannya mengenai suatu merek. Suatu merek yang telah mapan akan memiliki posisi yang menonjol dalam persaingan bila didukung berbagai asosiasi yang kuat. Asosiasi merek menurut Pettis (1995:106) adalah: "Brand associations a re attributes linked to the brand by customers." Berarti bahwa asosiasi merek adalah atribut-atribut (tidak tunggal) yang dihubungkan dengan merek oleh pelanggan, dengan kata la in asosiasi merek adalah gabungan dari berbagai atribut yang melekat pada pelanggan yang dihubungkan oleh merek. Mempunyai asosiasi merek yang kuat merupakan suatu keuntungan bagi badan usaha, dan asosiasi merek yang dimiliki oleh pesa ing juga sulit untuk direbut. Seperti yang dikatakan oleh Ries dan Trout, yang dikutip oleh Pettis (1995:106) "There is great power is owning a word (brand associations) in the customer's mind. And don't try to own a brand association already owned by someone else."

Menurut A. Belen del Rio (2001) brand associations dapat diukur dari dimensi fungsi merek yang terdin dari (1).The guarantee function, yaitu fungsi yang berkaitan dengan persepsi terhadap kualitas dan kinerja kualitas produk yang dijanjikan, (2). The personal identification function, yaitu fungsi yang berkaitan dengan perseps konsumen dalam mengidentifikasikan suatu produk dan mengembangkan rasa tertarik terhadap suatu merek, (3). The social identification function, yaitu fungsi yang berkaitan dengan persepsi konsumen terhadap kemampuan merek untuk menjalin komunikasi antar konsumen sehingga dapat mendekatkan konsumen dalam suatu kelompok di kelas sosial yang sama. Menurut Schiffman dan Kanuk (2004:375), Kelas sosial dalam masyarakat dibagi menjadi 5 kategori yaitu upper, upper-middle, middle, working, dan lower. serta (4.) The status function, yaitu kemampuan asosiasi merek untuk menimbulkan gengsi tertentu bagi konsumen yang menggunakan produk tertentu. 
Pada penelitian ini, menggunakan konsep brand association menurut Aaker dan konsep elemen pengukuran menurut $A$. Belen del Rio.

\section{Consumer Response}

Karena belum ditemukannya definisi atau konsep consumer response maka untuk mendapatkan pengertian tentang consumer response didekati dari konsep consumer dan response. Menurut Keegan (1995:7), "consumer is the user of a product." maka consumer dapat dideskripsikan sebagai orang yang menggunakan produk. Berdasarkan pengertian dari Dictionary Of Marketing and Business Tems (www.marketing.org.au) "Response is an effort to satisfy a drive. Rea ction evoked by a stimulus." maka response dapat dideskripsikan sebagai usaha konsumen yang tercemin dalam sikap dan perilakunya untuk memuaskan dorongan yang ada. Reaksi tersebut disebabkan oleh adanya rangsangan. Dari pengertian consumer dan response di atas maka dapat diambil menjadi suatu pengertian consumer response yakni menupakan penceminan dari sikap dan perilaku pengguna produk dalam memuaskan dorongan yang ada sebagai reaksi terhadap usaha-usaha pemasaran yang dilaksanakan perusahaan.

Studi perilaku konsumen mempelajari bagaimana seseorang membuat keputusan untuk mengelua rkan uang, waktu, dan usa ha dalam mengkonsumsi kebutuha nnya. Studi ini juga mempelajari apa yang dibeli konsumen; mengapa, kapan, dimana konsumen melakukan pembelian; berapa kali konsumen membeli produk; dan juga berapa kali konsumen menggunakan produk tersebut (Schiffman and Kanuk, 2004:8). Proses keputusan pembelian konsumen dimulai dari adanya keinginan konsumen untuk memenuhi kebutuhannya. Pada tahap ini konsumen a ware akan kebutuhannya. Kebutuhan ini dipenga ruhi oleh dua fa ktor: Pertama, fa ktor intemal, misalnya kebutuhan seseorang akan makanan dipengaruhi oleh rasa lapar. Kedua, faktor ekstemal, misalnya seseorang baru sadar terhadap kebutuhannya karena pengaruh iklan-iklan di media massa ataupun pesan dari direct mail (Kotler and Armstrong, 2004:223-224).

Proses keputusan pembelian merupakan serangkaian proses yang bersifat sequential, extensive, complex. Pada saat konsumen menentukan keputusan pembelian terhadap produk yang dinilai penting baginya, konsumen akan mengalami tahapan-tahapan proses keputusan pembelian. Proses pembelian ini disebut high involvement purchase process. Proses pembelian high involvement terjadi pada saat produk yang dibutuhkan konsumen relatif mahal, ja rang dibeli, berisiko, dan bemilai tinggi, contohnya rumah, mobil, komputer, rekreasi, dan produk-produk keuangan seperti a suransi jiwa (Kotler, 2005:221).

Respon konsumen memiliki tiga komponen yaitu cognitive, affective, conative. Cognitive response dinyatakan dalam knowledge dan perception konsumen terhadap suatu produk. Knowledge dan perception terbentuk karena awa reness 
dan information. Konsumen yang sadarakan kebutuhannya akan mencari infomasi mengenai produk kebutuhannya (Schiffman dan Kanuk, 2004:256).Proses yang terjadi dalam cognitive response ini memiliki kesamaan dengan proses keputusan pembelian dalam tahap need recognition dan tahap information search menurut Kotler dan Amstrong, atau tahap awareness dan tahap knowledge menurut Schiffman dan Kanuk. Awareness atau kesadaran konsumen tejadi pada tahap needs recognition (Kotler dan Amstrong) atau pada tahap a wa reness (Schiffman dan Kanuk). Knowledge konsumen yang terbentuk karena informasi dapat terjadi pada tahap infomation search (Kotler dan Amstrong) atau pada tahap knowledge (Schiffman dan Ka nuk).

Affective response dinyatakan dalam perasaan atau emosi konsumen melalui sika $p$ suka atau tida knya a ta upun penilaia n bagus tidaknya terhadap suatu produk. Sika ini merupakan hasil dari evaluasi konsumen terhadap suatu produk (Schiffman dan Kanuk, 2004:257-258). Jika pada tahap cognitive response, konsumen memiliki knowledge dan perception yang positif terhadap suatu merek produk tertentu, maka pada tahap affective response, konsumen akan membentuk suatu sikap yang positif pula.

Proses dalam affective response ini memiliki kesamaan dengan proses keputusan pembelian pada tahap evaluation. Pada tahap evaluation dalam buying decision process, konsumen melakukan evaluasi terhadap berbagai merek, membentuk sikap yang berbeda-beda terhadap masing-masing merek. Salah satu merek yang dianggapnya bagus dan disukai itulah yang akan dipilih dan dibeli.

Conative response menyangkut tindakan atau perilaku konsumen yang dinyatakan dengan intention to buy dan purchase (Schiffman dan Kanuk, 2004:258-259). Proses yang tejadi dalam conative response memiliki kesamaan dengan tahap purchase pada proseskeputusan pembelian.

Menurut A. Belen del Rio (2001) Consumer response dapat diukur dengan (1). Willingness to pay a price premium for the brand, yaitu kesediaan konsumen dalam membayar harga premium, (2). Willingness to accept brand extensions, yaitu kesediaan menerima produk hasil perluasan merek, Menurut Aaker (1991:208), "Brand extensions are a natural strategy for the fim looking to grow by exploiting his asset." Dengan kata lain perluasan merek adalah strategi alami untuk menumbuhkan perusahaan dengan mengeksploitasi aset yang dimiliki. Brand extension dapat dibagi menja di 7 pendekata $n$ yaitu: same product in different form, distinc tive taste / ingredient / component, companion product, customer fra nchise, expertise, benefit / attribute / feature, dan designer or ethnic image (Aaker, 1991: 211-212), dan (3). Willingness to recommend the brand to others yaitu kesediaan merekomendasikan produk ke orang lain. 
Pada penelitian ini, konsep consumer response menggunakan pendekatan dari konsep consumer menurut Keegan dan response menurut Dictionary Of Marketing and Business Tems serta konsep elemen pengukuran menurut A. Belen del Rio.

\section{Penganuh Brand Association terhadap Consumer Response}

A. Belen del Rio (2001), Hutton (1997), Yoo et al. (2000) menyatakan bahwa “Brand associations have a positive influence on consumer choice, preferences and intention of purchase, their willingness to pay a price premium for the brand, accept brand extensions, and recommend the brand to others", yang berarti bahwa asosiasi merek positif mempengaruhi pilihan atau kegemaran dan minat konsumen untuk membeli, serta kemauan untuk membayar harga premium, menerima perluasan merek dan merekomendasikan merek ke orang lain. Selain itu, suatu merek dika takan sesuai dengan nila i pelanggan jika dibedakan sesuai dengan level dan tipe consumer response.

Di dalam penelitian A. Belen del Rio (2001) tidak memasukkan consumer choice, preferences, and intention of purchase sebagai dimensi penelitiannya karena responden yang diteliti merupakan responden yang sudah pemah membeli produk itu, jadi tidak membutuhkan tahap consumer choice, preferences and intention of purchase dalam menentukan pembeliaannya (bukan lagi di tahap memilih produk yang a kan dibeli).

Maka menurut A. Belen del Rio (2001) a kan menarik apabila menganalisis pengaruh consumer response dari dimensi yang berbeda, yaitu dari kemauan untuk membayar harga premium, menerima perluasan merek, dan merekomendasikan merek ke orang lain. (The joumal of consumer marketing, Vol 18, 410-425)

\section{METODE PENEUTIAN}

Pada penelitian ini menggunakan jenis riset konklusif eksperimental. Karena penelitian ini bertujuan untuk mengetahui pengaruh antara dua variabel yang berbeda yaitu untuk mengetahui pengaruh brand associations terhadap consumer response pada produk Louis Vuitton di Surabaya.

\section{Variabel dan Pola Hubungan antar Variabel}

Variabel yang digunakan oleh peneliti untuk keperluan analisis penelitian ini terdin dari dua variabel (bivariate). Variabel yang menjadi variabel bebas (independent variable) a dalah brand association sedangkan variabel yang menjadi variabel tidak bebas (dependent variable) adalah consumer response. Pola hubungan antar variabel dalam penelitian ini temasuk dalam pola hubungan kausal atau sebab 
akibat, karena pengaruh brand association menjadi penyebab consumer response dan terja dinya consumer response merupa kan a kibat dari brand association.

\section{Definisi Operasional Variabel}

Definisi operasional variabel yang digunakan dalam pembahasan penelitian adalah sebagai berikut:

1. Brand association (BA) ya itu persepsi konsumen yang berkaitan dengan segala sesuatu dalam memori konsumen yang berhubungan dengan merek Louis Vuitton dan bukan hanya eksis tetapi juga memiliki tingkat kekuatan, yang diukur melalui the guarantee function, the personal identification function, the social identific ation function, dan the sta tus function.

2. Consumer response (CR) yaitu penceminan dari sikap dan perilaku orang yang menggunakan produk Louis Vuitton dalam memuaskan dorongan yang ada sebagai reaksi terhadap usaha-usaha pemasaran yang dilaksanakan oleh produsen Louis Vuitton (LVMH), yang diukur dengan willingness to pay a price premium for the brand, willing ness to accept brand extentions, dan willing ness to recommend the brand to others.

\section{Sumber Data}

Dalam melakukan penelitian ini digunakan data primer yang didapat dari pembagian kuesioner. Data diambil pada bulan Desember 2007. Pembagian kuesioner dilakukan di Surabaya yaitu di tempat-tempat perbelanjaan di Surabaya seperti Galaxy Mall, Pakuwon Supermal dan Tunjungan Plaza.

\section{Target dan Karakteristik Populasi}

Target populasi dari penelitian ini adalah orang yang membeli dan menggunakan produk branded fashion Louis Vuitton dan orang tersebut juga pemah membeli dan menggunakan produk branded fashion merek lain. Sedangkan karakteristik populasinya adalah orang yang membeli dan menggunakan produk branded fashion Louis Vuitton minimal selama 6 bulan, baik pria maupun wanita serta pemah membeli dan menggunakan produk branded fashion merek lain dan bertempat tinggal di Surabaya serta berpendidikan minima I SMU atau sederajat.

\section{Sampel dan Teknik Pengambilan Sampel}

Di dalam penelitian ini peneliti menggunakan sampel sebanyak 100 responden. Diharapkan dengan jumlah ini dapat memberikan gambaran mengenai tanggapan pelanggan terhadap brand association produk Louis Vuitton dan penga ruhnya terha dap consumer response produk Louis Vuitton. 
Teknik sampling yang digunakan adalah non probability sampling, yaitu teknik pengambilan sampel dimana tiap anggota populasi tidak mempunyai kesempatan yang sama untuk dijadikan sampel. Cara pengambilan sampel yang digunakan dalam penelitian ini adalah dengan convenience sampling yaitu mencari anggota populasi dengan cara temudah untuk mendapatkan informasi.

\section{Aras dan Skala Pengukuran}

Aras yang digunakan dalam penelitian ini adalah aras interval. Yaitu suatu ukuran memperlambangkan nilai relatif dengan interval yang bersifat homogen. Skala pengukuran yang dipergunakan adalah Numerical Scale, dimana responden diminta untuk memberikan penilaian, diukur dalam skala dan pada ujung pertanyaan ditutup dengan kata sifat. Contoh dari bentuk Numerical Scale, sebagai berikut: Tidak menarik 1,2, 3, 4, 5, 6, 7, Menarik

\section{Metode Pengolahan Data}

Sebelum dilakukan pengolahan data, terlebih dahulu dilakukan uji kehandalan dan keabsahan alat ukur ya itu kuesioner dengan menggunakan uji seperti di ba wah ini:

1. Uji Validita s

Validitas digunakan untuk menunjukkan seberapa baik suatu instrumen yang digunakan untuk mengukur suatu konsep tertentu menurut Sekaran (2000:207). Cara yang digunakan untuk mengukur validitas adalah dengan menggunakan konsistensi intemal (intemal consistency) yaitu dengan metode Pearson Product Moment yang dilakukan dengan menggunakan bantuan program komputer SPSS for Wind ows.

2. Uji Reliabilitas

a. Reliabilitas adalah kemampuan suatu instrumen menunjukkan kestabilan dan berkonsistenan di dalam mengukur konsep menurut Sekaran (2000:308). Dalam pengukuran reliabilitas ini dapat menggunakan cronbach alpha (a) yang menunjukkan seberapa bagus pemyataan berhubungan positif dengan pemyataan yang lain. Jika koefisien cronbach alpha bemilai 0,6 atau lebih maka instrumen itu dapat diterima.

Selanjutnya dilakukan analisis regresi linier sederhana dan analisis koefisien determinasi yang dibantu dengan program komputer SPSS for windows.

1. Regresi Linier Sederha na 
Ana lisis regresi linier sederhana menggambarkan pengaruh antara satu va riabel bebas (variable independent) yaitu BA dengan satu variabel tidak bebas (variable dependent) yaitu $C R$, dimana dalam penelitian ini dipergunakan untuk mengetahui pengaruh brand association terhadap consumer response secara keseluruhan. Persamaan regresi linier sederhana menurut Siagian dan Sugiarto (2000:224) :

$$
C \hat{R}=a+b \cdot B A
$$

Dimana :

CR = variabel tidak bebas, yaitu skor persepsi akan consumer response produk Louis Vuitton di Surabaya.

a = konstanta, yang menunjukkan besamya consumer response produk Louis Vuitton di Surabaya apabila brand association produk Louis Vuitton dipersepsikan konstan.

b = = koefisien regresi, menunjukkan besamya pengaruh brand association pada produk Louis Vuitton di Surabaya.

BA = variabel bebas, yaitu skor persepsi brand association produk Louis Vuitton di Surabaya.

Ana lisis Koefisiensi Determinasi

Koefisien determinasi ( $\left.r^{2}\right)$ merupakan suatu cara yang digunakan untuk mengukur seberapa besar variasi perubahan variabel brand association yang mampu menjelaskan variasi perubahan variabel consumer response produk Louis Vuitton di Surabaya. Bila $r^{2}=1$, dapat dikatakan bahwa variasi perubahan variabel brand association (BA) produk Louis Vuitton ini mampu menjelaskan varias perubahan variabel consumer response (CR) produk Louis Vuitton di Surabaya hingga $100 \%$. Bila $r^{2}=0$, dapat dikatakan bahwa variasi perubahan variabel brand association (BA) produk Louis Vuitton ini tidak mampu menjelaskan variasi perubahan variabel consumer response (CR) pada produk Louis Vuitton di Surabaya.

\section{Rancangan Uji Hipotesis}

1. Pengujian hipotesis t untuk nilai koefisien regresi (b)

Uji hipotesis yang digunakan dalam penelitian ini a dalah uji t melalui pengujian dua ekor (two tailed test) untuk menguji konstanta regresi dan koefisien regresi. Tingkat signifikansi yang digunakan di dalam penelitian ini adalah sebesar 0,05. Perumusan hipotesis da lam penelitia $n$ ini adalah sebagai berikut: 
$\mathrm{H}_{0}: \beta=0, \quad$ artinya brand association tidak berpengaruh secara signifikan terhadap consumer response produk Louis Vuitton di Surabaya .

$\mathrm{H}_{1}: \beta \neq 0, \quad$ artinya brand association berpengaruh secara signifikan terhadap consumer response produk Louis Vuitton di Surabaya.

Untuk menguji nilai b digunakan rumus:

$$
t=\frac{b}{S E \cdot b}
$$

dimana :

b : Koefisien regresi dari variabel bebas brand association produk Louis Vuitton di Surabaya

SE.b : Standard emror dari koefisien regresi dari variabel bebas brand association produk Louis Vuitton di Surabaya

$\mathrm{H}_{0}$ ditolak jika hasil print out dari program komputer SPSS for Windows menunjukkan $\mathrm{p} \leq 0,05$ yang berarti ada pengaruh brand association produk Louis Vuitton terhadap consumer response di Surabaya.

2. Pengujian hipotesis t untuk nilai konstanta a (intercept)

$\mathrm{H}_{0}: \alpha=0$; artinya konstanta intercept bukan menupakan estimator yang signifikan, dengan kata lain apabila brand association adalah konstan, maka consumer response produk Louis Vuitton di Surabaya dapat dianggap konstan secara statistik

$\mathrm{H}_{1}: \alpha \neq 0 ; \quad$ artinya konstanta intercept merupakan estimator yang signifikan, dengan kata lain apabila brand association adalah konstan maka consumer response produk Louis Vuitton di Surabaya tidak dapat dianggap konstan seca ra statistik.

Untuk menguji nilai a digunakan rumus:

$$
\mathrm{t}=\frac{\mathrm{a}}{\mathrm{SE} \cdot \mathrm{a}}
$$

dimana :

a : Konstanta regresi 


\section{SE.a : Standard errora}

$\mathrm{H}_{0}$ ditolak jika hasil print out dari program komputer SPSS for Windows $\mathrm{p} \leq 0,05$ yang berarti brand association yang konstan maka consumer response produk Louis Vuitton di Surabaya tidak dapat dianggap konstan seca ra sta tistik.

\section{Analisis Uji Validitas dan Reliabilitas}

Hasil pengujian validitas temadap kuesioner tentang brand association dengan menggunakan SPSS $\mathbf{1 5 . 0}$ for Windows, dapat dikatakan bahwa didapatkan hasil bahwa item-item pemyataan untuk variabel brand associations dianggap valid, hasil pengujian reliabilitas terhadap brand associations produk Louis Vuitton di Surabaya didapatkan nilai cronbach alpha adalah sebesar 0,801. Sedangkan hasil pengujian validitas terhadap kuesioner tentang consumer response produk Louis Vuitton di Surabaya yang juga dilakukan dengan SPSS 15.0 for Windows, dapat dikatakan bahwa didapatkan hasil yaitu item-item pemyataan untuk variabel consumer response valid, hasil pengujian reliabilitas terhadap consumer response produk Louis Vuitton di Surabaya didapatkan nilai cronbach alpha adalah sebesar 0,744 .

\section{Tampilan Data}

Pada kuesioner yang digunakan dalam penelitian ini terdapat 4 pemyataan mengenai brand associations dan 3 pemyataan mengenai consumer response pada produk Louis Vuitton di Surabaya. Brand associations dalam penelitian ini yang ada dalam kuesioner ditinjau dari dimensi the guarantee function, the personal identification function, the social identification function, dan the status function. Sedangkan atribut-atribut consumer response yang digunakan dalam kuesioner adalah willingness to pay a price premium for the brand, willingness to accept brand extention, dan willingness to recommend the brand to others.

Pemyataan-pemyataan brand associations yang terdin atas 4 dimensi tersebut adalah : pemyataan nomor 1 berkaitan dengan the guarantee function, pemyataan nomor 2 berkaitan dengan the personal identification function, pemyataan nomor 3 berkaitan dengan the social identification function, dan pemyataan nomor 4 berkaitan dengan the statusfunction.

Sedangkan pemyataan-pemyataan mengenai consumer response yang terdir dari 3 dimensi a dalah : pemyataan nomor 1 berkaitan dengan willingness to pay a price premium for the brand, pemyataan nomor 2 berkaitan dengan willingness to accept brand extentions, dan pemyataan nomor 3 berkaitan dengan willingness to recommend the brand to others. 
Data yang diperoleh dari hasil pembagian kuesioner selanjutnya diolah dengan menggunakan bantuan program SPSS 15.0 for Windows untuk mendapatkan nilai rata-rata hitung dan deviasi standar. Berikut ini akan ditampilkan tabel 6 yang menggambarkan hasil tanggapan responden terhadap brand associations produk Louis Vuitton di Surabaya.

Berdasarkan hasil pengolahan data kuesioner tentang brand associations terhadap produk Louis Vuitton di Surabaya, diketahui bahwa penilaian rata-rata para responden secara keselunuhan adalah sebesar 4,95. Hal ini berarti brand asso cia tions dari produk Louis Vuitton di Suraba ya ditinjau dari 4 dimensi pembentuk brand associationsyaitu the guarantee function, the personal identification function, the social identification function dan the status function dipersepsikan bagus oleh para responden. Sedangkan nilai deviasi standar atau simpangan baku adalah sebesar 0,86 yang berarti bahwa para responden rata-rata memberikan tanggapan yang bervariasi atas pemyataan mengenai brand associations dari produk Louis Vuitton di Surabaya.

Bila ditinjau dari rata-rata tiap pemyataan yang ada, dari 4 pemyataan yang ada mengenai brand associations produk Louis Vuitton di Surabaya, maka pemyataan yang memiliki skor rata-rata tertinggi/nilai rata-rata tertinggi adalah pemyataan nomor 2 yaitu dengan nilai rata-rata sebesar 5,29. Hal ini berarti para responden mempersepsikan bagus terhadap pemyataan "Kemampuan konsumen dalam mempersepsikan produk Louis Vuitton sebagai produk mewah" yang merupakan bagian dari dimensi the personal identific ation function.

Sedangkan pemyataan yang mempunyai skor rata-rata terendah dari brand associations produk Louis Vuitton di Surabaya adalah pemyataan nomor 4 yaitu "Kemampuan produk Louis Vuitton memberi kebanggaan kepada pemakainya" dengan nilai rata-rata 4,57. Akan tetapi meskipun pemyataan tersebut memiliki skor rata-rata nilai terendah, para responden tetap mempersepsikan bagus.

Berdasarkan hasil pengolahan data kuesioner mengenai consumer response pada produk Louis Vuitton di Surabaya, diketahui bahwa penilaian rata-rata para responden secara keselunuhan adalah sebesar 5,02. Hal ini berarti consumer response dari produk Louis Vuitton di Surabaya yang ditinjau dari 3 atribut pembentuk consumer response yaitu willingness to pay a price premium for the brand, willingness to accept brand extentions dan willingness to recommend the brand to others dipersepsikan bagus. Sedangkan deviasi standar atau simpangan baku adalah sebesar 0,84 yang berarti bahwa para responden rata-rata memberikan tanggapan yang bervariasi atas pemyataan yang diberikan kepada peneliti mengenai consumer response dari produk Louis Vuitton di Surabaya. 


\section{HASILDAN PEMBAHASAN}

\section{Hasil Pengolahan Data}

\section{a. Analisis Regresi Linier Sederhana}

Analisis regresi linier sederhana digunakan untuk menentukan apakah ada pengaruh dari brand associations (BA) terhadap consumer response (CR) produk Louis Vuitton di Surabaya. Berikut persamaan regresi linier sederhana mengenai pengaruh brand associations terhadap consumer response pada produk Louis Vuitton di Surabaya adalah sebagai berikut:

$$
C \hat{R}=2,280+0,5540 B A
$$

Dari persamaan di atas, dapat diketahui bahwa koefisien regresi (regression coefficient) pada persamaan linier sedemana menunjukkan kecendenungan marginal consumer response (CR) terhadap brand associations (BA) pada produk Louis Vuitton di Surabaya adalah bemilai positif/bersifat positif atau searah dengan nilai sebesar 0,554. Nilai sebesar 0,554 tersebut mempunyai arti jika tejadi perubahan brand associations produk Louis Vuitton di Surabaya mengalami kenaikan atau penununan sebesar satu satuan skor persepsi, maka skor consumer response terhadap produk Louis Vuitton di Surabaya juga akan mengalami kenaikan a ta u penununan sebesar 0,554 sa tuan skor persepsi.

Berdasarkan bentuk persamaan regresi linier sederhana di atas, juga dapat diketahui besamya nilai dari konstanta (a) yang menunjukkan nilai positif sebesar 2,280. Nilai tersebut mempunyai pengertian bahwa apabila brand associations produk Louis Vuitton di Surabaya dipersepsikan konstan, maka skor/nilai tanggapan consumer response produk Louis Vuitton di Surabaya adalah sebesar 2,280 satuan skor.

\section{b. Analisis koefisien deteminasi $\left(\mathbf{r}^{2}\right)$}

Analisis koefisien determinasi $\left(r^{2}\right)$ digunakan untuk menunjukkan seberapa besa $r$ variabilitas brand associations yang dapat menjelaskan consumer response, diperoleh hasil nilai koefisien determinasi $\left(r^{2}\right)$ sebesar 0,823 atau 82,3\%. Arti dari nilai koefisien deteminasi ini adalah bahwa variasi brand associations produk Louis Vuitton di Surabaya mampu menjelaskan variasi consumer response produk Louis Vuitton di Surabaya sebesar 82,3\% dan selebihnya yang sebesar 17,7\% dapat dijela skan oleh faktor-faktor la in yang tidak teramati. 


\section{Hasil Pengujian Hipotesis}

Pengujian nilai b (koefisien regresi) dan nilai a (konstanta) dari persamaan regresi linier sederhana tersebut signifikan a tau tidak signifikan, maka digunakan uji hipotesis t dengan menggunakan pengujian dua ekor atau two tailed test di mana level of significance $(\alpha)$ yang digunakan dalam penelitian ini a dalah sebesar $5 \%$ atau 0,05 .

Diketahui t hitung untuk nilai $\mathrm{b}$ adalah 6,842 dengan tingkat signifikansi dari b a da la $\mathrm{h} 0,000$ ata $0 \%$ sehingga $\mathrm{H}_{0}$ ditolak dan dianggap signifikan karena lebih kecil dari 0,05. Dengan kata la in b (koefisien regresi) merupakan estimator yang signifikan. Nilai b sebesar 0,554 merupakan estima tor yang signifikan dan bemilai positif, maka pengaruh yang terjadi adalah searah yaitu bila brand associations produk Louis Vuitton di Surabaya naik satu satuan skor, maka consumer response produk Louis Vuitton di Surabaya akan na ik sebesar 0, 554.

Pengujian nilai hitung a (konstanta) bertujuan untuk mengetahui a pakah konstanta (a) merupakan estimator yang signifikan. Diketahui bahwa t hitung untuk nilai a (konstanta) adalah 5,604 dengan signifikan dari a sebesar 0,000 ata u $0 \%$ sehingga $\mathrm{H}_{0}$ ditolak dan dianggap signifikan karena lebih kecil dari 0,05. Dengan kata la in konstanta a menupakan estimator yang signifikan. Nilai a sebesar 2,280 menupakan estimator yang signifikan, sehingga a pabila brand associations produk Louis Vuitton di Surabaya bagus, maka pelanggan produk Louis Vuitton di Surabaya juga akan memberikan respon yang bagus.

\section{Pembahasan Hasil Penelitian}

Setelah pengolahan data, maka variabel brand associations yang berkaitan dengan dimensi the guarantee function terlihat bahwa elemen yang diberikan produk Louis Vuitton di Surabaya yaitu keterjaminan garansi yang diberikan oleh Louis Vuitton mampu memenuhi harapan pelanggan Louis Vuitton Surabaya sehingga tercipta respon yang positif bagi pelanggan Louis Vuitton di Surabaya. Terhadap dimensi the personal identification function terlihat bahwa elemen yang diberikan oleh Louis Vuitton di Surabaya yaitu kemampuan konsumen dalam mempersepsikan produk Louis Vuitton sebagai produk mewah sangat memiliki peran penting dalam meningkatkan brand associations produk Louis Vuitton di Surabaya. Pada dimensi the social identification function, terlihat bahwa elemen yang diberikan oleh produk Louis Vuitton di Surabaya yaitu kemampuan produk Louis Vuitton untuk memudahkan konsumen menjalin komunikasi dengan anggota komunitas pengguna Louis Vuitton juga memegang peranan yang penting dalam meningkatkan brand associations produk Louis Vuitton di Surabaya. Adanya suatu kelompok di mana anggotanya adalah orang-orang yang menggunakan produk Louis Vuitton dapat menjalin suatu keakraban dan menciptakan suatu gengsi tersendin bagi para anggota kelompok tersebut. Pada dimensi yang terakhir dari brand associations yaitu the status function, terlihat bahwa elemen yang diberikan 
oleh produk Louis Vuitton di Surabaya yaitu kemampuan produk Louis Vuitton memberi kebanggaan pada pemakainya dapat meningkatkan brand associations produk Louis Vuitton di Surabaya. Kemampuan merek Louis Vuitton untuk mencipatakan image mahal yang dapat menimbulkan rasa bangga bagi para pengguna produk Louis Vuitton mampu meningkatkan consumer response dengan cara selalu berusa ha untuk meningkatkan dan menjaga image yang telah ada.

Hasil dari penelitian ini telah menunjukkan bahwa untuk meningkatkan consumer response produk Louis Vuitton di Surabaya dibutuhkan brand associations yang bagus dan berkua litas da ri produk Louis Vuitton di Sura baya, ka rena semakin ba gus brand associations yang diberikan oleh produk Louis Vuitton di Surabaya maka pelanggannya akan memberikan respon yang semakin bagus atas semua yang hal yang dilakukan oleh produsen Louis Vuitton. Hal ini didukung pula oleh teori dari A. Belen del Rio yang menyatakan bahwa brand associations memiliki penga ruh positif dan mempunyai peranan penting untuk mempengaruhi consumer response dalam hal pilihan konsumen, keinginan untuk melakukan pembelian, kesediaan konsumen untuk membayar harga mahal untuk membeli suatu produk, menerima perluasan produk dan merekomendasikan suatu merek kepada orang lain. Semakin bagus brand associations yang diberikan oleh produk Louis Vuitton di Surabaya maka respon yang diberikan oleh pelanggan juga semakin positif. Demikian juga sebaliknya.

Apabila tercipta suatu consumer response yang positif maka hal tersebut akan dapat memberikan keuntungan bagi produk Louis Vuitton di Surabaya. Akan tetapi sebaliknya, apabila pelanggan memberikan respon yang negatif, maka pelanggan akan berpindah ke merek lain. Ketika pelanggan merasa bahwa asosiasi merek yang dimiliki oleh produk Louis Vuitton di Surabaya adalah bagus sehingga pelanggan dari produk Louis Vuitton di Surabaya tersebut dapat memberikan respon yang positif, maka pelanggan akan bersedia untuk semakin loyal. Pelanggan akan cenderung untuk terus membeli produk Louis Vuitton di Surabaya untuk memenuhi kebutuhan dan keinginannya.

Berdasarkan hasil dari penelitian yang diperoleh dapat disimpulkan bahwa telah terbukti adanya pengaruh brand associations terhadap consumer response produk Louis Vuitton di Surabaya.

\section{SIMPULAN}

Konklusi penelitian adalah: brand association mempengaruhi consumer response, dengan koefisien regresi (b) sebesar 0,5540 dimana tingkat signifikansi (a) 5\%. Adapun koefiesien determinasi $\left(r^{2}\right)$ yang diperoleh nilai $82,3 \%$ yang menunjukkan bahwa variasi brand a sso ciations produk Louis Vuitton mampu dijela skan oleh va rias consumer response sebesar $82,3 \%$, sedangkan sisanya yang sebesa $17,7 \%$ dijela skan oleh fa ktor-fa ktor lain yang tidak diteliti. 
Implika si

Berdasarkan beberapa konklusi yang telah dikemukakan di atas, maka untuk selanjutnya dapat dikemukakan beberapa implikasi, baik secara teoritis maupun praktis.

1. Implikasi secara teoritis

J ika suatu produk dipersepsikan oleh pelanggan memiliki asosiasi merek yang bagus, maka semakin bagus asosiasi merek sebuah produk tersebut, dan semakin besarpula pengaruhnya terhadap consumer response. Apabila sebuah merek memiliki consumer response yang kuat maka konsumen akan memberikan reaksi-reaksi yang positif terhadap hal-hal yang dilakukan oleh produsen merek tersebut. Hal ini didukung oleh $A$. Belen del Rio, yang menyatakan bahwa consumer response berkaitan erat dengan brand asso ciations.

Apabila consumer response tinggi maka akan membuat pelanggan senantiasa loyal dan bahkan mungkin merekomendasikan hal ini kepada orang lain sehingga dapat terja di peningkatan penjualan, peningkatan pangsa pasar dan pada akhimya mendatangkan keuntungan bagi badan usaha dengan adanya peningkatan laba.

2. Implikasi secara praktis

Secara praktis, diketahui bahwa responden memberikan penilaian yang bagus terhadap brand a sso ciations dan consumer response, produk Louis Vuitton yang dapat dilihat dalam penelitian ini. Responden mempersepsikan bahwa produk Louis Vuitton memiliki asosiasi merek yang bagus dan dapat mengakibatkan consumer response yang bagus dan positif.

Usaha-usaha untuk meningkatkan brand associations Louis Vuitton perlu dilakukan, karena dengan brand associations yang tinggi, maka consumer response yang tinggi pun akan tercipta. Consumer response yang tinggi akan membuat pelanggan senantia sa loyal dan bahkan mungkin merekomendasikan hal ini kepada orang lain sehingga dapat terjadi peningkatan penjualan, peningkatan pangsa pasar dan pada akhimya mendatangkan keuntungan bagi badan usaha dengan adanya peningkatan laba. 
Rekomendasi

Berdasarkan keseluruhan pembahasan dalam penelitian ini, maka akan disampaikan beberapa rekomendasi yang berguna bagi produsen produk Louis Vuitton, yaitu sebagai berikut :

1. Badan usaha perlu memperhatikan dimensi the status function dari brand associations pada "Kemampuan produk Louis Vuitton memberikan kebanggaan kepada para pemakainya", karena mempunyai nilai yang paling rendah dibandingkan dimensi-dimensi yang lain.

2. Produsen hendaknya juga meninjau lebih lanjut akan hal pemyataan pertama, yaitu "Kesediaan konsumen membayar harga mahal untuk mendapatkan produk Louis Vuitton", yang termasuk dalam dimensi willingness to pay a price premium for the brand pada consumer response karena memiliki nilai yang paling rendah dibanding kan dengan dimensi-dimensi yang lain.

3. Secara keseluruhan produsen produk Louis Vuitton hendaknya selalu menjaga serta meningkatkan brand associations-nya, karena mengingat sekarang ini banyak pesaing yang menawarkan produk serupa dengan manfaat, kualitas, dan harga yang cukup bersaing. Hal ini ditujukan agarpelanggan Louis Vuitton tetap loyal dan tidak mudah beralih ke pesaing yang lain, juga dapat pula menyebabkan pelanggan tersebut berkenan untuk merekomendasikan produk Louis Vuitton kepada orang lain sehingga bisa mendatangkan keuntungan bagi produsen produk Louis Vuitton.

\section{DAFTAR REFEENSI}

Aaker, David A.. 1991. Managing Brand Equity: Capitalizing on the Value of a Brand Name. The Free Press. New York.

Belen del Rio, A., Rodolfo Vazquez, dan Victor Iglesias.. 2001. The Effects of Brand Asso ciations on Consumer Response. The J oumal of Consumer Marketing. 18: 410-426.

Durianto, D., Sugia rto, dan Sitinjak T.. 2001. Strategi Menaklukkan Pa sar melalui Riset Ekuitas dan Perilaku. PTG ramedia Pustaka Utama. Jaka rta.

Hutton, James G.. 1997. A Stud y of Brand Equity in a n Organiza tional-Buying Context. J oumal of Product and Brand Management. 6(6): 428-439.

Keegan, Warren J., Sandra E. Moriarty and Thomas R. Duncan. 1995. Marketing, Sec ond Edition. Prentice Hall Inc.. Englewood Cliffs. New J ersey.

Keller, Kevin Lane. 1993. Conceptualizing, Measuring, and Managing CustomerBa sed Brand Equity. J oumal of Marketing. 57: 1-22.

Kinnear, Thomas C, Kenneth L dan Kathleen A. Krentler, Principles of Marketing, Forth Edition, Harper Collin Publisher, New York, 1995.

Kotler, Philip. 2005. Marketing Management: Analysis, Planning, Implementation, and Control, Sixth Edition. Prentice-Hall. New York. 
Kotler, Philip, dan Gary Armstrong. 2004. Principles of Marketing, Ninth Edition, Prentic e-Hall Intemational Inc.. New J ersey.

Pettis, Chuck. 1995. Technobrands: How to Create and Use Brand Identity to Market, Advertise, and Sell Technology Products. American Management Association. New York.

Schiffman, Leon G dan Leslie Lazar Kanuk. 2004. Consumer Behavior, Eighth Edition. Prentic e-Hall Intemational Inc.. New J ersey.

Sekaran, Uma. 2000. Research Methods for Business: A Skill Building Approach, Third Edition. J ohn Wiley and Sons, Inc.. Singapore.

Siagian, D dan Sugiarto. 2000. Metode Statistika untuk Bisnis dan Ekonomi. PT. Gramedia Pustaka Tama. Jakarta.

Yoo, B., Donthu, dan Lee, S. 2000. An examination of Selected Marketing Mix Elements and Brand Equity. Joumal of Academy of Marketing Science. 18(2): 195-211.

http://www.businessweek.com/brand/2006

http://www.jaka rta consulting.com/art-01-11.htm

http://www.korantempo.com

http:// www.louisvuitton.com/web/fla sh/ind ex.jsp;jsessionid=Y3WEO RMQ SZ4O O CRBX UXFAHYKEG 4RAUPU? buy=1\&langue =en_GB

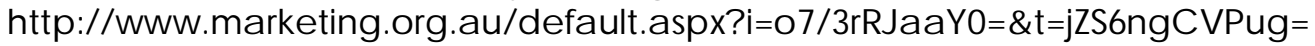
http://en.wikipedia .org/wiki/Louis_vuitton

*kndklnjfhjosd khfksd 